\title{
外来がん化学療法における疑義照会内容の医療経済学的検討
}

\author{
川島理恵子*，相良英憲，河崎陽一，横山紀子， \\ 松香直行，松永 尚，千堂年昭，五味田 裕 \\ 岡山大学病院薬斉部
}

\section{Medical Economics Evaluation of Pharmacist Intervention in Outpatient Antineoplastic Chemotherapy}

\author{
Rieko Kawashima*, Hidenori Sagara, Yoichi Kawasaki, Noriko Yokoyama, \\ Naoyuki Matsuka, Hisashi Matsunaga, Toshiaki Sendo and Yutaka Gomita \\ Department of Pharmacy, Okayama University Hospital \\ $\left[\begin{array}{l}\text { Received May 9, } 2007 \\ \text { Accepted A ugust 2, } 2007\end{array}\right]$
}

\begin{abstract}
Increasing medical expenses have become a serious social problem so it is necessary for all medical staff, including hos pital pharmacists, to conduct medical treatment from the viewpoint of economy. In this regard, we estimated the economic effect of checking prescriptions in outpatient antineoplastic chemotherapy between June 2004 and May 2005. Seventy three of 81 pharmacist inquiries resulted in prescription changes Twenty inquiries concerning changes to more appropriate drugs achieved cost savings of 454,633 yen and 19 inquiries, which probably prevented serious adverse events, were considered to achieve savings of 2,161,820 yen based on an evaluation using the Diagnosis Procedure Combination (DPC). These results suggest that pharmacists make a significant contribution to controlling medical expenses in outpatient antineoplastic chemotherapy as well as to making it more effective and safer.
\end{abstract}

Key words — medical economics, outpatient antineoplastic chemotherapy, check prescriptions, management of hospital

\section{緒言}

病院薬斉師は処方鑑査，薬斉管理指導業務，医薬品の 情報提供等，日々の業務を通じて有効で安全な薬物治療 の推進に努めている.さらに，今日多く報道されている 薬闵事故の問題から鑑みると, リスクマネージメント上 からも臨床現場への薬阂師の積極的な関与が求められて いる．すなわち薬阁師の業務は今後ますます拡大してい くものと思われる .

一方, 少子・高齢化や医療の高度化・複雑化が進み， 医療費の増加が社会的な問題となっている．限りある医 療費の抑制策として, 診断群分類(Diagnosis Procedure Combination; DPC)による医療費包括化，診療報酬改 定，規制改革などの医療制度改革が行われている.この ような状況下において，病院は医療の質を向上し，維持 しながらも可能な限り医療の無駄をなくすという経営努
カがより一層必要とされる . 病院薬剂師をはじめとする 医療従事者も，医療経済学的な観点から業務を行う必要 がある・よって，拡大する薬阂師業務を医療経済学的に 評価することは，医療経済に対する薬阂師の貢献性を検 討する上で重要な意味を持つと考える．

薬斉師業務の医療経済学的な評価は米国等において多 数行われている.Mutnickら ${ }^{11}$ は薬剂師の臨床現場への 薬学的介入が, 薬阂費節減や入院日数の短縮と光れに伴 う医療費節減をもたらすことを報告している．日本にお いても，薬斉師が医薬品の適正使用へ積極的に関与する ことにより医療費を節減できることが報告されてい $る^{2,3)}$ ．しかし，薬阂師業務を医療経済学的に評価した報 告は, 日本では諸外国に比較して非常に少ないのか現状 である。

岡山大学病院(以下, 当院と略す)では, 薬剈師は外来 がん化学療法において, 処方鑑査および抗悪性腫瘍斉混 合調製業務等を行っている.これまでわれわれは当院外 
来がん化学療法において, 処方鑑査を通じて有効で安全 な化学療法の施行に積極的に関与していることを報告し てきた ${ }^{4.5)}$. 本研究では, 当院外来がん化学療法の処方鑑 査時に行った疑義照会の内容を医療経済学的に評価し， 薬剂師の医療経済面からの関与について検討した . まず，治療効果に直接影響を与えない，適切な薬㓢規格 への変更に関する疑義照会と，光れ以外の疑義照会に分 類した，適切な薬剂規格への変更に関する疑義照会か ら，薬剤費節減額を調査した。また，適切な薬斉規格へ の変更以外の疑義照会のうち, 重大な副作用を回避でき たと考えられるものを抽出し，副作用発現の回避による 医療費節隇額を概算しだ・.

\section{方法}

\section{1. 調査期間と対象}

調査期間は 2004 年 6 月から 2005 年 5 月までの 1 年間 とした . この間当院で施行された外来がん化学療法の件 数はのべ 2,736 件であり，光れに対して処方鑑査時に疑 義照会を行い，処方変更か認められたものを対象とした (表 1).

2. 薬阂規格の変更による薬剤費節減額の算出 疑義照会を内容ごとに分類し集計した。複数規格が存 在する薬斉で, 調製後の薬剂の残余が少なくなるよう適 切な規格に变更依頼したものを，薬斉規格に関する疑義 照会とした . 薬阂規格に関する疑義照会について, 薬価

表 1. 外来抗がん剂混合調製の実績と疑義照会率

\begin{tabular}{l|c}
\hline & 1 年間の総数 \\
\hline 抗がん剂および前投薬の混合調製本数 & 6,914 本 \\
\hline 抗がん剂混合調製本数 & 4,324 本 \\
\hline 前投薬混合調製本数 & 2,590 本 \\
\hline のべ患者数 & 2,736 名 \\
\hline 疑荤照会件数 & 81 件 \\
\hline 疑義照会率 & $2.96 \%$ \\
\hline
\end{tabular}

の変更前後の差額に, 变更時以降の処方回数を乗じて算 出した．なお，薬価基準は2004年4版を用いた。

計算式 : $\{$ (変更前の薬剤費) $-($ 変更後の薬剤費 $)\} \times$ 処方 回数

○薬斉費減額の例

カルボプラチン注 $500 \mathrm{mg}$ 処方 :

$450 \mathrm{mg} 1 \mathrm{~V}+150 \mathrm{mg} 1 \mathrm{~V} \rightarrow 450 \mathrm{mg} 1 \mathrm{~V}+50 \mathrm{mg} 1 \mathrm{~V}$ への 処方変更

13,572 円 $=\{(150 \mathrm{mg}$ バイアル $[20,907$ 円 $] \times 1)-(50 \mathrm{mg}$ バイアル $[7,335$ 円 $] \times 1)\} \times 1$

○薬剂費増額の例

リツキシマブ注 $600 \mathrm{mg}$ の溶解液 $540 \mathrm{~mL}$ 処方 :

生食 $500 \mathrm{~mL}$ と生食 $100 \mathrm{~mL}$ 処方 $\rightarrow$ 生食 $500 \mathrm{~mL}$ ボトル $+20 \mathrm{~mL} 2$ アンプルへの処方変更

- 93円 $=\{(100 \mathrm{~mL}$ ボトル[97 円] $\times 1)\}-(20 \mathrm{~mL}$ アン プル[64円]×2) $\} \times 3$

3. 副作用発現回避による医療費節減額の概算

本研究では, 副作用の治療にかかる医療費を Mutnick ら"の手法を用いて DPC に当て嵌め概算し，医療費節減 額として評価した . 適切な薬剂規格への変更に関するも の以外の疑義照会のうち，重篤な副作用が発現する可能 性があるものを抽出した . 仮に重篤な副作用が発現し患 者が入院を余儀なくされた場合，急性期医療としてDPC No.161070(薬物中毒(谷の他の中毒))に分類される. 本研 究では, 入院中に手術や検査・処置はせず, 副病名もな いものとした . 患者が入院期間 Iまでの4日間入院した 場合，入院費は 113,780 円となる $\{(3,271$ 円 $\times 2$ 日 $+2,418$ 円 $\times 2$ 日) $\times$ 医療機関別係数 $\}($ 表 2). これを疑義照会 1 件 あたりの医療費回避額として算出した。なお，2004年 度における DPC および医療機関別係数 1.0213 をいて 算出した。

〈疑義照会 1 件あたりの医療費節減額〉

113,780 円 $=\{$ 入院期間 |での1日あたりの点数(3,271

表 2.DPC における薬物中毒(兴の他の中毒)の診断群分類点数の詳細

\begin{tabular}{|l|r|}
\hline 診断群分類番号 & $1610703 \times 99 \times 0 \times x$ \\
\hline 診断群分類名称 & 藥物中毒 (その他の中毒) \\
\hline 入院期間 I & 3 \\
\hline 入院期間 II & 5 \\
\hline 特定入院期間 & 6 \\
\hline 入院期間 I 日未満の点数 & 3,271 点 \\
\hline 入院期間 I 日未満の点数 & 2,418 点 \\
\hline 入院期間 I 日以上の点数 & 2,055 点 \\
\hline 手術 & なし \\
\hline 手術·処置等2 & なし \\
\hline 副傷病 & なし \\
\hline
\end{tabular}


円) $\times$ 日数(2日間) + 入院期間 IIでの1日あたりの点数 $(2,418$ 円 $) \times$ 日数 $(2$ 日間 $)\} \times$ 医療機関別係数 $(1.0213)$

\section{結果}

1. 疑義照会の内訳と変更率

2004 年 6 月から 2005 年 5 月までの 1 年間に行った疑 義照会の内訳と変更率を図 1 に示した.全疑義照会は 81 件であり, 処方変更が認められたのは 73 件(変更率 90.1 \%)であった．关のうち薬剂の規格に関する疑義照会が

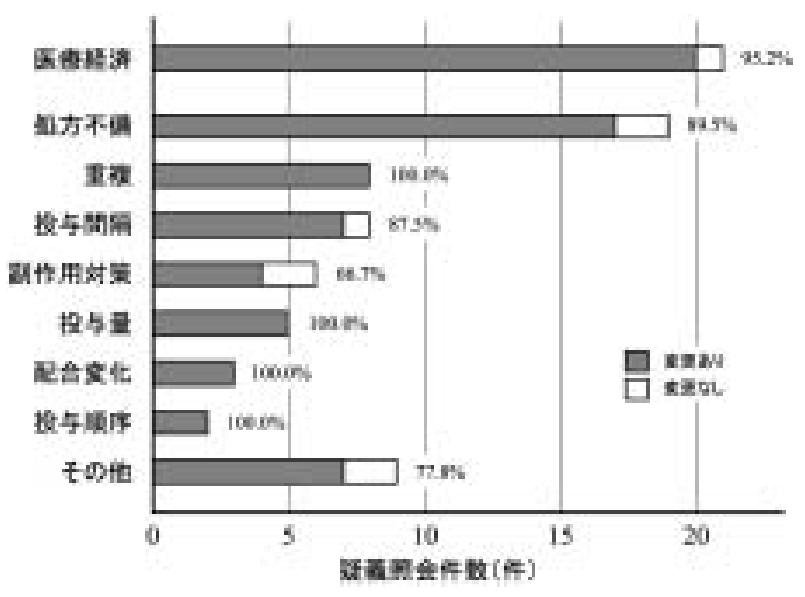

図 1 . 疑義照会の内訳と変更率
21 件(変更率 95.2\%)と最も多く, 次いで処方不備に関す るもので 19 件(変更率 89.5\%), 重複 8 件(変更率 100.0 $\%)$, 投与間隔 8 件(変更率 $87.5 \%$ ), 副作用対策 6 件(変 更率 $66.7 \%$ ), 投与量 5 件(変更率 $100.0 \%$ ), 配合変化 3 件(変更率 $100.0 \%$ ), 投与順序 2 件(変更率 $100.0 \%$ ), 光 の他 9 件(変更率 $77.8 \%$ )であった．薬斉規格以外の疑義 照会 60 件のうち処方変更されたのは 88.3\% にあたる 53 件であった .

\section{2. 適切な薬剂規格への変更による薬剂費節減額}

適切な薬剂規格への変更による薬剂費節減額の結果を 表 3 に示した . 薬阁の規格に関する疑義照会 21 件のう ち, 変更が認められたのは 95.2\% にあたる 20 件であつ た . 弚の薬剂費節減額は 454,633 円であった . 規格変更 の対象となった薬剂には，イリノテカン8件が最も多 く, 以下カルボプラチン 4 件 , ゲムシタビン 1 件 , ドセ タキセル 1件, フルオロウラシル 1 件, 生理食塩液 5 件 であった . 疑義照会時以降の処方回数は 1 回から最多で 22 回であった . 処方回数を考慮すると，1件当たりの薬 価差額は-93円から最高 148,148円であった .

\section{3. 副作用発現回避による医療費節減額}

薬剂規格の変更に関するもの以外の疑義照会で, 重篤 な副作用が起こる可能性のある疑義照会内容から医療費

表 3. 薬剂規格変更の疑義照会の詳細と薬斉費節減額

\begin{tabular}{|c|c|c|c|c|}
\hline No. & 変更前 & 変更後 & $\begin{array}{c}\text { 変更時以降の処 } \\
\text { 方回数(回) }\end{array}$ & $\begin{array}{c}\text { 薬価差額 } \\
\text { (同) }\end{array}$ \\
\hline 1 & フルオロウラシル $775 \mathrm{mg}$ & フルオロウラシル $750 \mathrm{mg}$ & 9 & 4,149 \\
\hline 2 & カルボプラチン $500 \mathrm{mg}$ 処方に $450 \mathrm{mg} 1 \mathrm{~V}$ と150 mg 1V & $450 \mathrm{mg}$ 1Vと50 mg IV & 1 & 13,572 \\
\hline 3 & イリノテカン $90 \mathrm{mg}$ 処方に40 mg 3V & $100 \mathrm{mg} 1 \mathrm{~V}$ & 22 & 148,148 \\
\hline 4 & イリノテカン $90 \mathrm{mg}$ 処方に $=40 \mathrm{mg} 3 \mathrm{~V}$ & $100 \mathrm{mg} 1 \mathrm{~V}$ & 4 & 26,936 \\
\hline $\begin{array}{l}5(\mathrm{No} .3 \\
\text { と同一) }\end{array}$ & イリノテカン $90 \mathrm{mg}$ 娢方に40 mg 3V & $100 \mathrm{mg} 1 \mathrm{~V}$ & - & - \\
\hline 6 & イリノテカン $90 \mathrm{mg}$ 処方に40 mg 3V & $100 \mathrm{mg} 1 \mathrm{~V}$ & 11 & 74,074 \\
\hline $\begin{array}{l}7 \text { (No.6 } \\
\text { と同一) }\end{array}$ & イリノテカン $90 \mathrm{mg}$ 姃方に $=40 \mathrm{mg} 3 \mathrm{~V}$ & $100 \mathrm{mg} 1 \mathrm{~V}$ & - & - \\
\hline 8 & カルボプラチン $400 \mathrm{mg}$ 処方に50 mg 8V & $150 \mathrm{mg} 2 \mathrm{~V}$ ट $50 \mathrm{mg} 2 \mathrm{~V}$ & 5 & 10,980 \\
\hline 9 & カルボプラチン $183 \mathrm{mg}$ 処方に $150 \mathrm{mg} 2 \mathrm{~V}$ & $150 \mathrm{mg} 1 \mathrm{~V} と 50 \mathrm{mg} 1 \mathrm{~V}$ & 1 & 13,572 \\
\hline 10 & カルボプラチン $316 \mathrm{mg}$ 処方に $150 \mathrm{mg} \mathrm{3V}$ & $150 \mathrm{mg} 2 \mathrm{~V} と 50 \mathrm{mg} 1 \mathrm{~V}$ & 7 & 95,004 \\
\hline 11 & ゲムシタビン1 g処方に200 mg 5V & $\lg 1 \mathrm{~V}$ & 11 & 20,680 \\
\hline 12 & リツキシマブ $600 \mathrm{mg}$ の溶解液に生理食塩液 $500 \mathrm{~mL}$ 生理食塩液 $100 \mathrm{~mL}$ & 生理食塩液 $500 \mathrm{~mL}$ と生理食塩液 $20 \mathrm{~mL} 2 \mathrm{~A}$ & 3 & -93 \\
\hline 13 & リツキシマブ600 mgの溶解液に生理食塩液500 mLと生理食塩液 $100 \mathrm{~mL}$ & 生理食塩液 $500 \mathrm{~mL}$ と生理食塩液 $20 \mathrm{~mL} 2 \mathrm{~A}$ & 1 & -31 \\
\hline 14 & リツキシマブ $600 \mathrm{mg}$ の溶解液に生理食塩液 $500 \mathrm{~mL}$ と生理食塩液 $100 \mathrm{~mL}$ & 生理食塩液 $500 \mathrm{~mL}$ と生理食塩液 $20 \mathrm{~mL} 2 \mathrm{~A}$ & 2 & -63 \\
\hline 15 & イリノテカン $160 \mathrm{mg}$ 処方に100 mg IVと40 mg 2V & $40 \mathrm{mg} 4 \mathrm{~V}$ & 3 & 6,582 \\
\hline 16 & イリノテカン130 mg処方に40 mg 4V & $100 \mathrm{mg} 1 \mathrm{~V} と 40 \mathrm{mg} 1 \mathrm{~V}$ & 1 & 6,734 \\
\hline 17 & イリノテカン133 mg処方に100 mg 2V & $100 \mathrm{mg} \mathrm{1Vと40} \mathrm{mg} \mathrm{1V}$ & 2 & 22,244 \\
\hline 18 & リツキシマブ溶解液の生理食塩液 $540 \mathrm{~mL}$ 処方に生理食塩液 $1000 \mathrm{~mL} 1 \mathrm{~B}$ & 生理食塩液 $500 \mathrm{~mL}$ 1Bと生理食塩液 $20 \mathrm{~mL} 2 \mathrm{~A}$ & 3 & -54 \\
\hline 19 & 生理食塩液 $250 \mathrm{~mL}$ 処方に生理食塩液500 mL 1B & 生理食塩液 $250 \mathrm{~mL} 1 \mathrm{~B}$ & 1 & 0 \\
\hline 20 & ドセタキセル $70 \mathrm{mg}$ 処方に $20 \mathrm{mg} \mathrm{4V}$ & $80 \mathrm{mg} 1 \mathrm{~V}$ & 1 & 12,198 \\
\hline \multicolumn{4}{|r|}{ 合計 } & 454,633 \\
\hline
\end{tabular}


回避額を概算した結果を表 4 に示した . 本研究では，パ クリタキセルの前投薬であるジフェンヒドラミン錠やデ キサメタゾン注等の処方不備，抗がん斉の処方重複，パ ミドロン酸二ナトリウムや抗がん斉の投与間隔，パクリ タキセルとドセタキセルの処方間違い, シクロホスファ ミドの溶解液など，いずれも重大なアナフィラキシーや 悪心・嘔吐など，疑義照会を行わなかった場合，著しい 患者の不利益が予想される19件を評価対象とした . 兴 の結果，2,161,820 円の治療費を節減できたと推定され た(表 4).

\section{考察}

当院では当初，医師は施行する化学療法を決定すると 患者ごとのプロトコールを薬斉部に提出し，医師が処方 オーダを行っていた．2006年10月より，外来がん化学 療法のプロトコール審査委員会か設置され，承認された プロトコールを基に医師が処方オーダを行っている . よって, 薬斉師は処方オーダがプロトコールに逸脱して いないかどうかを確認することが重要である．処方鑑査 時に薬剂師は，プロトコールの確認(患者名，性別，身 長, 体重, 合併症の有無, 薬剂名, 投与量, 投与回数, 投与間隔, 総投与回数, 投与経路, 投与方法, 投与順序, 投与時間)とともに, 必要な補助薬の有無, 配合変化の 有無, 溶解液の量, 溶解後の安定性および必要に応じデ バイス・輸液フィルター等を確認している．今回，外来 がん化学療法の処方鑑査時に行った疑義照会の内容を医 療経済学的に評価し, 薬斉師の医療経済的な貢献につい
て検討した．調査期間中の疑義照会は 81 件であり，う ち73件で変更が認められた . 変更が認められなかった のは, 前回生じた強い嘔気に対する前投薬処方追加の依 頼や，抗がん剂内服の処方依頼，シクロホスファミドの 適切な薬剂規格への変更依頼, 溶解液量, 白血球減少に 対する化学療法施行の確認，投与間隔に関するもので あった . 原因としては, 薬剂師のがん化学療法に対する 所見とは異なり，医師の所見から変更しない方が妥当で あると判断されたためと考えられた . 変更の有無に関わ らず, 薬斉師が薬剂師の立場から安全で有効ながん化学 療法の施行に携わることが必要であると考える．

本研究より, 適切な薬剂規格への変更による疑義照会 から，454,633 円の薬剂費が節減できたことが明らかと なった . 外来においては, 薬剂費は出来高払いであるこ とから，積極的な薬剂規格の適正化により，患者の医療 費負担の軽減および医療費抑制に貢献できるものと考え られる．また，患者によっては疑義照会以降同一の処方 で 22 回施行されており, 最高で 148,148円の薬剂費の 節減に寄与できた例もあった . がん治療では患者の経济 的負担は非常に大きく，治療選択や治療継続を決定する 上で重要な要因の一つである．QOL 向上や医療の進歩 を背景にがん化学療法は入院から外来へ移行し，患者の 医療費負担が軽減される方向に向かっているとはいえ， 経済的および社会的に与える影響は多大なるものであ る .すなわち，薬剂師が薬剂の規格適正化に関する疑義 照会を積極的に行うことにより，薬物治療の選択肢を拡 大し , 治療継続に貢献できると考えられた .

調製後の薬斉の残余が少なくなるよう規格変更した場

表 4.DPC を用いて評価した疑義照会の詳細と各概算金額

\begin{tabular}{|c|c|c|c|}
\hline No. & 疑義照会の分類 & 疑義照会内容 & 変更後 \\
\hline 1 & 処方不備 & パクリタキセルの前投薬にジフェンヒドラミン錠なし & シフェンヒドラミン鎵処方追加 \\
\hline 2 & 投与間隔 & トラスツズマブ150 mg/body+パクリタキセル60 mg/body、2週間連続で処方 & 中止 \\
\hline 3 & 投与間隔 & 2日前に同様の処方 & 中止 \\
\hline 4 & 投与間隔 & パクリタキセル2週間ごとのプロトコールで2週間連続で処方 & 中止 \\
\hline 5 & 好方不備 & パクリタキセルの前投薬にデキサメタソンなし & デキサメタゾン追加 \\
\hline 6 & 処方不備 & パクリタキセルの前投薬にデキサメタゾンなし & デキサメタソン追加 \\
\hline 7 & 処方不備 & パクリタキセルの前投薬なし & 前投桼追加 \\
\hline 8 & 投与間隔 & $\begin{array}{l}\text { ビルルルビン (day } 1,8)+ \text { カルボプラチン (day1)プロトコールでday8にビルルルビンと } \\
\text { カルボプラチンの処方 }\end{array}$ & カルボプラチン中止 \\
\hline 9 & 投与量 & ドセタキセル $120 \mathrm{mg} / \mathrm{body}$ & パクリタキセル $120 \mathrm{mg} /$ bodylに変更 \\
\hline 10 & 配合変化 & シクロホスファミドの溶解液に蒸留水 & 蒸留水から生理食塩液に変更 \\
\hline 11 & 投与間隔 & 3週間ごとのプロトコールで1週間後に処方 & 中止 \\
\hline 12 & 重複 & 抗癌剂処方重複 & 重複分中止 \\
\hline 13 & 投与間隔 & パミドロン䣷ニナトリウム2週間連続で処方 & 中止 \\
\hline 14 & 重複 & 抗癌剂処方重複 & 重複分中止 \\
\hline 15 & 投与間隔 & パミドロン酸ニナトリウム2週間前にも投与あり & 中止 \\
\hline 16 & 投与量 & Baxter Infuser Pump $5 \mathrm{~mL} / \mathrm{hr} 46 \mathrm{hr}$ 投与で生理食塩液 $18 \mathrm{~mL}$ 溶解指示 & 生理食塩液 $180 \mathrm{~mL}$ に変更 \\
\hline 17 & 重複 & 抗癌凨処方重襙 & 重複分中止 \\
\hline 18 & 重複 & 抗癌剂処方重複 & 重複分中止 \\
\hline \multirow[t]{2}{*}{19} & 重複 & 抗癌剖処方重複 & 重複分中止 \\
\hline & & 合計 & $2,161,820$ 円 \\
\hline
\end{tabular}


合 , 薬斉費は増額となることもある . 疑義照会の中には リツキシマブ注の溶解液である生理食塩液の規格を変更 依頼し，最高 93 円の増額となった例もあった。しかし この場合，生理食塩液の残余はなくなるため，量り取る 際のリスクを回避できたと考える

適切な薬斉規格への変更以外の疑義照会から, 照会が 行われなかった場合，副作用が発現したことを仮定し， 炎の治療にかかる費用を医療費節減額として概算した . 患者自身や患者背景，患者の病態などにより，副作用の 発現頻度や重症度は変化することが予想されるが, 本研 究では特に重症化が予測される疑義照会内容を抽出し， DPC に当て嵌め評価を行った . がん化学療法において 入院を要するほどの重大な副作用としては, 嘔吐, 下 痢, 好中球減少症を伴う発熱, アナフィラキシーショッ クなどが挙げられるが, 本研究ではどの副作用が発現し ても該当するDPC コードとして「薬物中毒(弚の他の中 毒)」を用いて概算した，弚の結果，2,161,820 円の医療 費増が回避されたと推定された .これらのことは, 薬剤 師が処方鑑査を行うことにより，副作用発現を防止し， かつ将来的に発生すると考えられる副作用治療にかかる 医療費を未然に節減しているものと考えられる。

本研究により, 薬斉師が外来がん化学療法に積極的に 関与することで, 有効で安全な化学療法の施行に貢献で きるだけでなく，医療費抑制の面からも寄与しているこ とが示唆された。 DPCによる包括支払い制度が開始さ れ，医療の無駄を省きつつ質の高い医療を提供すること が病院に求められている.医薬品の適正使用およびリス クマネジメント上重要な役割を担う薬斉師が, 臨床現場 において積極的に活躍することか医療経済学的検討から も重要であると考えられた .

本研究は, 薬剂師の必要性を検討する知見の一助とな
ると考える . 近年, 社会から求められる多大な責務にも 関わらず，薬阂師の人員確保は病院の経営面から困難で あることも多い．しかし，薬阂師がリスクマネージャー としての役割を果たし，医薬品の適正使用の推進に寄与 し，さらに医療費抑制に貢献していることから，光の社 会に対する貢献度は非常に大きいものと考える。

\section{引用文献}

1) A.H. Mutnick, K.J. Sterba, J.A. Peroutka, N.E. Sloan, Cost savings and avoidance from clinical interventions, Am. J. Health-Syst. Pharm., 54, 392-396 (1997).

2) 伊勢雄也，島崎麻智子，片山志郎，注射斉調剂によ る適正使用推進と医療経済的効果，月刊薬事，47, 755-759 (2005).

3）伊勢雄也, 室田陽右, 高山幸三, 成田年, 鈴木勉, 宋静香, 片山志郎, 平野衾, NSAIDs の術後疼痛に 対する処方状況並びに副作用発現における因子の解 析, 薬学杂隹誌， 123，613-618 (2003).

4) 日野美波理, 二神幸次郎, 五味田裕, 外来化学療法 への取り組み一外来化学療法における薬剂師の役 割，薬事新報，2328, 9-12 (2004).

5) 日野美波理, 石井雅人, 藤原聡子, 松香直行, 定金 典明, 森山雅弘, 二神幸次郎, 柴田和彦, 五味田裕, 外来がん化学療法における薬剂師の関与のあり方, 医療薬学，30, 457-467 (2004).

6) 後藤伸之, 渡辺享平, 矢野良一, 塚本仁, 青野浩直, 萱野勇一郎，脇屋義文，政田幹夫，副作用回避を経 済的に評価する指標としての副作用にかかる費用に 関する調査研究谷の 1 . 医薬品による重篤な皮膚障 害にかかる費用(急性期入院医療機関別包括評価 (DPC)と医薬品副作用被害救済制度を利用した概 算), 疾療薬学 , 31, 399-405 (2005). 